\title{
Discourse Coalitions in the Controversy around the HydroAysen Project in the Patagonia Region of Chile
}

\author{
María Eugenia Merino $^{1} \&$ María Elena Bello ${ }^{2}$ \\ ${ }^{1}$ Faculty of Education, Universidad Católica de Temuco, Chile. \\ ${ }^{2}$ Institute of International Studies, Universidad de Chile, Chile. \\ Correspondence : María Eugenia Merino, Faculty of Education, Universidad Católica de Temuco, Chile. \\ Received: February 16, 2014 \\ Accepted: March 17, 2014 \\ Available online: April 22, 2014 \\ doi:10.11114/ijsss.v2i3.395 \\ URL: http://dx.doi.org/10.11114/ijsss.v2i3.395
}

\begin{abstract}
This paper explores the discourse coalitions that became evident during the conflict around the HydroAysen hydroelectric megaproject in the Patagonia region of Chile. We explore three nodal concepts around which the coalitions were constructed and the argumentative and rhetoric strategies used.

The analysis, inspired by a socio constructivist approach and based on Hajer's argumentative method (2005), studies 40 discourse allocutions from relevant leaders and social actors publically available through national press releases and web pages between 2011 and 2012.

Findings reveal the presence of two discourse coalitions holding competing views. The first coalition includes the President of the Republic of Chile and the Ministry of Energy, together with the proposing hydroelectric company. This coalition displays a neoliberal socioeconomic-oriented argumentation based on the proposition that the Chilean energy crisis can be resolved through hydroelectricity, a natural resource abundant in the Patagonia, which would bring more development and connectivity to the Aysen region. The second coalition, made up of social and environmental groups 'Patagonia Without Dams' and 'Aysenines against HidroAysen' exhibits a more socio-environmental oriented argumentation. Their narrative revolves around the absence of a national energy policy which makes the country economically vulnerable to the establishment of mega projects such as the HydroAysen project that may benefit only a few enterprises but ruin unique environments such as that in Patagonia.

We conclude that these antagonistic coalitions run along assymetric processes of discursive institutionalization. Furthermore, the HydroAysen case analysis contributes to explain the way discourse coalitions contribute to the failure of Chilean democracy to build social consensus on contentious issues.
\end{abstract}

Keywords: discourse coalitions: hydroelectric mega project: citizens' voices

\section{Introduction}

The aim of this paper is describe the discourse coalitions arising from the controversy around the proposed construction of the HydroAysen megaproject in the Patagonia region of Chile. We first explore the relevance of the problem and discuss pertinent scholarship, theoretical orientations, and our research strategy. The method section describes sample selection, size and data collection. The analysis of the data, inspired by Hajer's argumentative method (2005), is described. This approach explores how a particular sociopolitical problem is related to the type of narrative which is problematized, discussed and argued about. Finally, in the discussion section we interpret the results of our analysis and discuss the implications of antagonistic discourse coalitions in the current debate on hydroelectricity in Chile.

In Chile there is a lack of clarity about the environmental issues that concern the country, how they affect and how they are perceived by citizens (Hajek et. al, 1990). Furthermore, there is lack of regulatory regulations, no framework for environmental use, and little knowledge about the ecological effects that various ways in which water resources are used may cause (Monreal et. al., 2012). In recent years there has been widespread sociopolitical debate about the nature of the most appropriate energy matrix in Chile. The government of President Piñera, which was in power until March 2014 affirmed that by the year 2020 electricity consumption will increase by a projected $6 \%$, meaning that an increase of 100,000 GWh of electricity will be demanded per year. In this context hydroelectric mega-project, HydroAysen from ENDESA [(National Electricity Enterprise Public Corporation.) and Colbun enterprises was proposed, entailing the 
building of five dams in the Aysen region. This project would generate $18.430 \mathrm{GWh}$ per year, however it would bring with it various negative outcomes. Six thousand hectares of Patagonic valleys would be flooded, and the impact on virgin flora and fauna would negatively impact eco-tourism, which is one of the region's main economic activities (Castilla \& Leyton, 2010). In addition to this damage to the eco-system, the destruction of natural landscape, the local population displacement, and the impediments to fish migration patterns would affect the region's population's health (Montoya-Aguilar, 2009). While the Aysen region is vulnerable to this particular proposal, it has been suggested that $45 \%$ of Chile is at risk of exposure to large projects of this type (Fuenzalida \& Quiroz, 2011).

In 2012 President Piñera's government launched the 'National Energy Strategy Plan 2012-2030' which identified hydroelectricity as one of the pillars of the Chilean energetic matrix, and subsequently the local governmental Commission for Environmental Evaluation at Aysen approved the HydroAysen project. However, this was not supported by the general public with surveys such as that conducted by a national paper, La Tercera (2011), indicating that up to $74 \%$ of the population opposed the project. Environmental groups that opposed the project, particularly 'Patagonia without Represas' and 'Ayseninos against H.A' argued that no opportunity to negotiate alternative solutions had been offered, so they prepared the 'National Plan for Energy Development', a less environmentally interventionist alternative that contemplates the introduction of nonconventional renewable energy (www.patagoniasinrepresas.cl).

In the context of the lack of a national energy policy with specific regulations regarding hydroelectricity (La Nacion national paper, 2012) and the tensions between the government and ENDESA on the one side, and environmental groups on the other, since 2012 the HydroAysen hydroelectric project has been paralyzed. HydroAysen's associated enterprises are uncertain about the project's implementation (www.biobiochile.cl; Tuesday, January 28, 2014), although the project has not been discarded from the company budget. The future of the project was further muddied when there was a change of government in March 2014, and the new government, led by President Michelle Bachellet, declared that hydroelectricity and the future of HydroAysen will be subjected to ample public debate before a decision is reached. Nevertheless, in the recent debate leading up to the election, President Bachellet declared that the HydroAysen project is not feasible (The Financial Paper; Monday, June 24, 2013).

Understanding discourse coalitions in the sociopolitical controversy of the HydroAysen project has theoretical and practical implications. The formulation of energy policies necessarily needs to consider the socioeconomic and political interests of the involved actors who, by means of their discourse, shape and define the problem from their particular view of reality. In the majority of cases different models of reality in interaction may generate conflicts because they may not be compatible, and one vision excludes the other. This can be observed in the current political conflict around HydroAysen whose relational dynamic leads to one coalition, that with governmental support, dominating the political arena. This however over-rides citizens and the locals' demands so, in order to make themselves heard they use social pressure such as street demonstrations and sometimes violent actions.

Finally the study of HydroAysen conflict may contribute with new knowledge to highlight and explain the failure of Chilean democracy to build social consensus on contentious matters, and at the same time it may also offer information to other democratic systems of the region on how to address institutional weaknesses and conflict, and advance toward more stable and richer democracies.

\section{Conflicts in global and local contexts}

World environmental problems are generally based on economic issues, where anthropocentric neoliberal logic understands natural resources as commodities and services (Tietenberg, 2001), thereby engendering conflicts between local communities and big enterprises (Folchi, 2001;Toledo et al, 2009). Routledge (2003) argued that evolving modernist governments in developing countries, as in Chile, tend to reinvent modes of coercive state legitimacy through developmental discourses that reveal practices and power strategies of elite actors. One example of this is when a government acts as a donor of national resources to powerful companies. Citizens in these countries are seen as "witnesses" whose political identity is regularly neutralized and neglected by a more technical type of discourse of development, which allows no counter voice in the political and economic arena.

The importance of water, one of the most precious resources, and the struggles to dominate it (physically and discursively) has generated numerous socio-environmental conflicts. This is particularly the case when the construction of mega dam projects is proposed. This can be seen, for example in the construction of the Sanxia dam or 'Three Gorges' project in China. When directly affected the locals voiced their concerns, they were silenced by the Chinese government (Edmonds, 1992; Hvistendahl, 2008; SacaleWatts, 2011). In India, an organized resistance was articulated by academic technical analysis, peasant testimonials and slogans in opposition to the Sardar Sarovar mega dam built in Narmada River Valley Their opposition was overridden by the government (Rigg, 1991; Routledge, 2003) which used its narratives about water scarcity as a discursive tool to legitimize the dam, and at the same time neglect the needs of the deprived in water-limited areas (Mehta, 2001). The Ethiopian case of the Gabe dam cascade reflects a similar socio-environmental narrative pattern in which part of the affected tribes (the Omo) built rights-based discourse around 
their cultural and heritage traditions that clashed with the government's economic development based discourse (Abbink, 2012). Further, struggles for water resources have caused conflicts between neighboring countries, as the case of Gabcikovo and Nagymaros dams on the Danube river between Slovakia and Hungary. In the latter country a movement against the dam (the Danube Circle) was founded, demanding that the communist government release information and open debate on the dam's environmental impact. This group discursively redefined the social understanding of the dam, shifting it into a symbol of the old communist regime (Williams, 1994). A similar case involved Turkey, Syria and Iraq, when the former used the dam 'GAP' as a tool of political and military strategy against the latter countries (Jongerden, 2010).

Clearly, conflicts arising from large scale dam projects have their origin in the polarized narratives that depict opposed world views and development models (Khagram, 2004; Abbink, 2012). To understand this Bingham (2010) analyzed in detail the conflict between the Amazon indigenous people and the proponents of the Belomonte dam in Brazil. By using Hajer's analysis of argumentative discourse he showed that such socio environmental conflicts have their roots in opposite narratives, one holding a socio-economic based development view and the other a socio-environmental perspective, each conceptualizing reality in a different way.

In other Latin America countries this dynamic is not far different. Large hydroelectric mega projects have been built in drainage areas mainly inhabited by rural aboriginal people. Such projects often threaten to reshape indigenous local territories, their economy and culture. This logic of modernization and economic development collides with the worldview of locals who share discourses and common interpretative schemas about nature, and especially water (Svampa, 2012). This can be observed in numerous countries, including El Salvador, where 'Frente Social para un Nuevo País' opposed the Cimarron hydroelectric project (Pérez, 2009), and Mexico, where the 'Council of Ejidos' and communities opposed the hydroelectric La Parota dam project' (Landa, 2012). Conflict has also been evident in Guatemala and Panama. In Guatemala the hydroelectric DEORSA and DEOCSA projects have been opposed by the 'National movement of indigenous rural communities' (Hirsh \& Utreras, 2010), and in Panamá there is a conflict between the Chan-75 hydroelectric project and the Ngöbe aboriginal people. In this case, Ngöbe aboriginal people have not been consulted about the dam construction, therefore violating collective indigenous rights (AIDA, 2009). In a similar line there are conflicts between countries such as Argentina and Paraguay where the binational Yacyretá project has caused serious cultural and environmental damage to indigenous Mbya people and local Argentinean fishermen (AIDA, 2009).

The above cases highlight the fact that socio-environmental conflicts around the globe share a similar pattern: enterprises, generally supported by the government, make alliances with heterogeneous actors including politicians and bureaucrats (Khagram, 2004). They promulgate the idea that, despite the apparent contradictions between public and private agents, both are promoting the advancement and consolidation of entrepreneurial forms of water management. Their case is grounded on merely formal and not substantive democratic governance (Castro, 2008). In most cases socio environmental conflicts are based on weak legal and environmental policies that omit the right of consultation, participation, determination and information of the affected communities (Khagram, 2004; Castro, 2008; Ascelrad, 2010; Landa, 2012). Finally as these mega projects are generally constructed without local approval, it seems unavoidable that environmental groups and locals make alliances to fight against issues of injustice, inequity, sustainability and violations of indigenous rights. These coalitions make their opposition public and impose their vision as an alternative to dam monopolies (Shiva et al, 1991; McCully, 2001; Khagram, 2004).

\section{The Current Study}

The epistemological basis of the present study is social constructionist (Foucault, 1984; Gergen, 1996, Hajer \& Versteeg, 2005; among others) which claims that social and public phenomena are creatively, flexibly and contextually constructed by social actors in interaction. The analytic attention then moves towards the role of discourse as social practice in cognitive, evaluative and categorization processes (Edwards, 1997;Potter, 2005). From the perspective of discourse analysis, Laclau et al. (1985) and Howarth et al. (2000) state that reality cannot be directly presented but it is made through discourse which constructs a 'representation' of reality. Language then has the capacity to 'make' politics, 'create' signs and symbols that shift power balances, 'render' events harmless or, on the contrary, 'create' political conflicts.

Our research strategy uses Hajer's approach (1995) which studies from a discursive perspective the nature of problems of modern societies such as urban planning, technologic development policies, and environmental and energy policies. Hajer applies a discursive perspective to the formulation of political and public issues, focusing on their origin and the role of diverse actors with different backgrounds, who do not necessarily share ideological or values coherence. This approach offers greater flexibility and breadth to the study of sociopolitical phenomena such as political/environmental conflicts. The richness and innovative focus of the method lies in the fact that sociopolitical controversies are not directly derived from the complexity of ideologies and positions of involved actors but are a result of the dispute of attaching particular meanings to ideas through narrative lines. For Hajer (1993), politics is first given 
in the language space, being manifested in discourse, and then it becomes embedded in public policies, projects and regulations.

Hajer's argumentative method (1995) postulates that in a narrative the actor builds a particular problem by constructing his own version about facts and events in the shape of a story or narrative lines. These are used within particular situations and contexts and become the argument through which actors try to impose their own view of reality on others. For Hajer, argumentative analysis is not centered on the coherence of an argument but on its interpretative reading and understanding. Thus, the reader or hearer reflects whether the argument 'sounds credible'.

When a group of actors share the same set of practices (routines, rules and norms that give coherence to social life) and also use the same or similar narrative lines to reproduce and transform specific discourses, a discourse coalition is built. Discourse coalitions are then the 'making' and 'doing' of a public and discursive phenomenon, contingent on local and contextual conditions of production. Furthermore, Hajer (2006) points out that in analyzing political discourse, attention must be paid to power relations, institutions and domination. This brings up the concept of discursive institutionalization which arises when a particular discourse is solidified into specific institutional plans, regulations or laws. The study of discourse reveals how diverse actors actively engage in defining a public phenomenon and develop a deep understanding of what a problem is about. This is why discourse analysis fulfils a prominent role in the study of environmental politics and policy making because understanding how a problem is conceptualized by particular discourses may provide the solution for such problems. So, illuminating discourses allows for a better understanding of controversies, not in terms of rational argumentation, but in terms of the argumentative rationality that people bring to a discourse (Hajer, 2005).

We approach our study by analyzing discourse samples from relevant social and political leaders involved in the HydroAysen conflict available from Chilean national press releases and web pages between 2011 and 2012. To do this we focus on Hajer's analytical categories: nodal concepts, story lines, discourse coalitions, and discursive institutionalization. We also focus on argumentation and the discursive and semantic strategies that build it, such as descriptions, generalizations, polarizations, and metaphors as a rhetoric tool. In order to identify and describe the discourse coalitions that emerged from the conflict around the HydroAysen hydroelectric megaproject in the Patagonia region, we pose the following main questions: Which are the main nodal concepts displayed in the allocutions and which narrative lines sustain them? Which discursive coalitions emerged around the HydroAysen project proposal and how is the political arena structured? How does discursive institutionalization operate in the controversy?

\section{Method}

The data for the current study is part of a larger research developed between 2011 and 2012, a particularly relevant period of time in which the local governmental Commission on Environmental Evaluation at Coyhaique, Aysen region, approved the HydroAysen project. This caused citizens to unleash an outburst of social demonstrations and public allocutions in defense of the region's natural environment. The total data gathered consisted of 60 discourse allocutions in national press releases and web pages emanating from 9 relevant political leaders and 9 social and environmental groups and actors.

Actors identification was on the basis of an exhaustive review of the high impact popular media including national newspapers 'La Nación', 'El Mercurio' (on line version Emol), 'El Magallanes' (Aysen regional newspaper), 'El Divisadero' (Aysen regional newspaper), radio interview programmes at 'Cooperativa' (national radio), government official web pages, HydroAysen official web page, and web pages of national and local environmental groups.

For the present study we have selected 40 narratives and their actors who have publicly expressed their positions regarding the HydroAysen project. For ethics consideration persons' names have been removed and replaced by their respective honorific titles. These include the President of the Republic, the Minister of Energy, HydroAysen executives, and environmental groups 'Patagonia Without Dams' and 'Aysenines Against HidroAysen'. The method for analysis considered the following sequence: a) revealing nodal concepts from allocutions b) depicting story lines, argumentation, discursive and semantic strategies and metaphors c) grouping storylines around similar representations of reality d) confirmation of discourse coalitions e) establishment of discursive institutionalization.

Symbols being used in the citings below are: (...) shows that the extract is the continuation of a previous discourse, $[\ldots]$ indicates that some non relevant parts of the discourse have been omitted to avoid unnecessary extension of the text (Jefferson, 2004).

\section{Findings}

Two discourse coalitions about the HydroAysen project proposal were revealed. The first group comprises the President of the Republic, the Ministry of Energy, and representative executives of the HydroAyse project. The second coalition is made up of various local (Aysen region) and national socio-environmental groups. The two coalitions display opposing story lines but build their discourse around three nodal concepts: 'representations of the energy situation of the 
country', 'views about the economic and environmental development of Aysen region', and 'the role of citizens in decision making concerning the project'. The main story lines of the government/ HydroAysen executives coalition relates to the 'crisis' in the country's energy situation and the HydroAyse project being the solution. Story lines on the part of 'Aysenines against HydroAysen' and 'Patagonia without Dams' argue that the lack of a national energy strategy plan affects local communities whose development is based on tourism and the natural environment. Furthermore, they hold that the HydroAysen project favors only a few elite businessmen from the capital of the country.

\subsection{Representations of the Energy Situation of the Country}

Representations of the country's energy state of affairs and the direction of its future energy policy give birth to two different narrative lines regarding the economic development of the country. On the one hand, the government and HydroAysen share the vision that hydroelectricity is synonymous to development. This is seen on HydroAysen's web page where Europe, Australia and the USA are used to illustrate the case of developed countries that have taken hydroelectricity as one of their energy pillars.

(...) for example hydroelectric development in Europe, North America and Australia reach the $75 \%$ whereas Latin America has only developed $33 \%$ of its total resources.

The meaning underlying this narrative line reveals the argument that Latin American developing countries need to take the example of those that are already developed. By using the strategy of comparison HydroAysen presents these as successful models emphasizing that Latin American countries are far behind ("only 33\%").

Similarly in La Nacion daily the President of the Republic emphasizes the above belief affirming that "Chile is a hydroelectric possibility" so "we have to use water because it is energy" and we "have to use it to the benefit of the nation's development".

It is interesting to note that the government and HydroAysen display dramatic narratives in order to convince citizens about the benefits of approving the proposed project. In El Mercurio Emol daily an executive spokesman of HydroAysen states:

(...) if we end up without constructing HydroAysen you'll get half of the SIC with no future at all [...] the situation then becomes more critical.

In this excerpt the executive presents the energy issue as critical and argues that HydroAysen is essential to reinforce Chilean SIC (Interconnected energy system) which currently links the south with the central part of the country. HydroAysen construction would eventually expand to connect the north and ensure that the energy demand of the whole country can be met. The speaker uses an extreme formulation (with no future at all) to describe the prospective bleak future of the country without HydroAysen., causing a more vivid effect on the hearer (the situation then becomes more critical). This argument is particularly effective in the context of a country like Chile whose long and varied geography makes interconnection difficult and expensive.

Likewise, the President of the Republic in a Cooperativa radio programme expresses his concerns about the uncertainty of H.A. construction.

\section{(...) if we do not take decisions now we are condemning our country to a blackout at the end of the decade [...].}

The President's argument aims to convince citizens that it is today's generation's responsibility to decide the energy future of the country. His narrative is supported by the warning metaphor 'condemn the country to a blackout' displaying a dramatic vision of the country's future energy. If the energy crisis is not addressed now the country is likely to subside into complete darkness in the near future.

On the other hand, 'Patagonia Without Dams' and 'Aysenines against H.A.' hold the vision that the HydroAysen project does not contribute to an equitable development of the country, because it benefits only an elite group of entrepreneurs in Santiago. In its web page 'Patagonia without Dams' declares:

(...) more than 2.235 kilometers of cables in order to inject cheap energy to the already saturated and overpopulated capital of the country [...] all this in impairment of the regions.

The above story line displays a vivid narrative of a prospective view of Aysen's deteriorated landscape if HydroAysen installed 2.235 kilometers of cables, and positions the capital and its citizens as the only beneficiaries of the new project. The underlying meaning of this narrative pictures the capital as a 'greedy big brother who eats his siblings' food'.

At 'El Magallanes' daily 'Aysenines against H.A' reinforce the above story lines.

(...) Hydroaysen does not fit the necessary factors [...]for the development we long for since the very fact of its implementation will deviate us from the real aim, which is [...] that may light illuminate us all and not only a few. 
HydroAysen's company aims are perceived by Aysenines as divergent from locals' wishes for regional development. Furthermore it is seen as favoring only the capital's energy needs. By using the metaphor 'may light illuminate us all, and not only a few' Aysenines also display their representation of the capital of the country as the 'big greedy brother who eats his siblings' food'. This representation acquires validity in the regions since it is a fact that Santiago has historically consumed most of budget distribution and made political decisions for the country and its citizens.

In a similar way, another metaphor recreates the above argument at local paper 'El Magallanes'.

(...) we cannot become 'el pato de la boda' (the marriage party duck) and allow us be sacrificed due to the wrong management of Chilean energy policy.

The metaphor 'the marriage party duck' connotes situations in which somebody has to be sacrificed in order to benefit others because there is no other choice. Metaphorically, Aysenines present themselves as the 'duck' of the government 'energy dinner' to which they have not been invited. Neither have they been consulted about the political decisions regarding the HydroAysen project.

\subsection{Views about the Economic and Environmental Development of Aysen Region}

However, both groups share the need for more connectivity between the Aysen region and the rest of the country. For HydroAysen and the government, connectivity is synonymous to economic development, as it is stated on the HydroAysen web page.

(...) from its beginnings H.A. has declared that benefiting its citizens is one of its main priorities [...]benefiting its inhabitants through the offer of more work posts, training programes [...] these are important connectivity opportunities [...] that will allow Aysenines a better integration with the rest of the country.

HydroAysen's narrative in this excerpt emphasizes that its main focus is on benefiting Aysen citizens through the provision of more jobs and technical training, and connectivity to the rest of the country. Likewise in El Mercurio Emol daily, the President of the Republic backs up the above declaration by using a vivid description of the Aysen region, highlighting its natural beauty and size.

(...) we'll benefit Aysen citizens [...] we'll be integrating this marvelous territory that represents an important part of the national territory for more development and opportunities.

In his declaration the President personalizes his intentions by presenting himself as an active participant in the project (we'll) and attaching important value to Aysen natural territory; however the President's representation of the problem is clearly anthropocentric which can be seen in his narratives where people are more important than the environment, as he declares in an interview at Cooperativa national radio program.

\section{(...) I am more worried about Chileans, because people deserve more protection than trees.}

The President's statement together with HydroAysen's above reveal that both share the view that the development of the HydroAysen project to benefit the people of the region through more work posts and job training is more important than any preoccupation with the natural environment of the territory.

On the other hand, 'Patagonia without Dams' holds a more conservationist perspective on regional development based on nature conservation. For example, in its webpage this group declares.

(...) we want to develop our region on the basis of conserving its environmental attributes and territorial integrity [...] the touristic potential of the Patagonia is directly dependent on its exceptional natural resources and environmental beauty which would be irreversibly damaged by H.A.

In this storyline it becomes clear that Aysenines' main aspirations are nature preservation and the touristic potential of their region, and the HydroAysen construction represents an end to their notion and hopes for regional development. The mental state of 'wanting' (we want to develop) is a cognitive resource that displays the speakers' positioning of beliefs and desires, in this case a balanced interrelationship between natural beauty and touristic potential. Aysenines' view of HydroAysen's intervention is highlighted by the term "irreversibly damaged" that provides dramatization to the argument.

To the above environmental concerns of Aysenines, the government has proposed some mitigation measures. For example, in the National Strategy Plan 2012-2030 the Ministry of Energy states:

(...) a special plan will be developed to fully protect the Chilean Patagonia, allowing the extension of protection and exclusion of generation and transmission initiatives within large zones of resources of exceptional condition.

The vagueness and ambiguity of the above declaration is noticeable. Vague descriptions allow the speaker to divert attention from sensitive points of the argument, in this case what type of protection will be provided, what type of initiatives will be excluded, and what is meant by 'large zones of resources of exceptional condition'. Furthermore, by 
stating that there will be a 'special' plan to protect the Patagonia excludes other natural zones of exceptional beauty like 'Torres del Paine' in the south and the geysers at 'San Pedro de Atacama' in the north. This reveals that the government Strategy Plan has been developed compelled by the contingency of environmental issues that have arisen in the recent years and not from a long term, wider and inclusive perspective.

In the same way, in its web page HydroAysen offers a set of measures to mitigate the potential eventual harm, being its discourse more technical and concrete.

(...) an area of conservation of 11.560 hectares will be created, more than 4.500 forest hectares will be reforested, native fish species in danger will be cared for by controlling predator introduced species (like salmon and trout) recuperating their population will allow their artificial reproduction.

This narrative displays a pseudo convincing argument. The creation of large conservation areas and reforestation would require in fact a long term period, a decade at least. In the meantime the touristic potential of the region would suffer the damage, with the HydroAysen construction affecting locals' source of income. Protection of endangered indigenous fish by controlling the introduced predator species would also take considerable time. Through the strategy of corroboration and consensus, the argumentation aims at convincing the reader by using technical and scientific language that is cognitively associated to veracity and objectivity, a type of truth.

\subsection{The Role of Citizens in Decision Making}

This nodal concept displays the role of citizens in HydroAysen project conflict. Depending on how each group represents the concept of citizen participation, their narrative lines attribute actors an active or passive role in decision making. For example, in its web page HydroAysen states its position about citizens' role in the development of the project.

(...) we get every home involved by informing about the various activities that we develop and the advance of our project.

HydroAysen assigns the citizen a unidirectional passive and receptor role: information is passed on to the citizen but there is an absence of active interaction in decision making which creates an asymmetric relational pattern between citizens and HydroAysen. The argument displayed by HydroAysen uses the emotional resource of proximity and empathy ("we get every home") whose underlying effect is to make the reader believe that HydroAysen executives are actually visiting the locals at their places to talk about the project, which was not the case.

Similarly, the Ministry of Energy in the National Strategy Plan 2012-2030 reveals the government's stand on the level of citizen participation in environmental projects.

(...) the aim is to deepen dialogue instances and antecedents that are delivered to the citizenship [...] this will allow improving environmental management of the sector, improve decisions about the location of projects, protect our environmental patrimony and generate informed debates.

Although the introductory statement "to deepen dialogue instances" announces an eventual participation of citizens in environmental projects, the supporting argument sets the citizen in a passive role since the "antecedents that are delivered to the citizenship" have already been structured. Generating "informed debates" would discuss topics previously settled by the Ministry of Energy, and citizens representatives are expected to improve decisions already taken, for example, the 'location' of the projects. Hence, citizens are left without input into the original decision about environmental projects in relation to their regional welfare.

On the other hand 'Patagonia without Dams' and 'Ayseninos without dams' attribute the citizen and the locals an active and central role in the discussion of the type of electricity development that Chile requires, and uphold the concept of 'citizenship consultation'. This is clearly expressed by one of the leaders of 'Patagonia without Dams' in an interview given to 'El Mercurio Emol' daily.

(...) the government must look for instances for citizenship participation [...] and of the regions in order to reach consensus on where, when and how the country electric development will be done.

In the same line, 'Aysenines without Dams' demand from the government a more active role for the affected communities, as read at 'El Mercurio Emol'.

(...) what is primary concern is that the people of the Patagonia speak, we have never been asked if we are in favour or against this or other projects.

This story line highlights the need the voice of the people to be heard and demands more citizenship participation in the political process. 
Finally, it is worth noting that the government and HydroAysen, and 'Patagonia without Dams' have held some roundtables to try to resolve the conflict; however no agreement has been reached. 'Patagonia without Dams' subsequently announced its withdrawal from the discussions as it can be read in the following declaration.

(...) nonetheless some meetings have been held with the authorities, we realize that our counterpart, the government, has no interest in considering our opinion, of those who live in the territory that are the target of project intervention [...] the government's actions and attitudes towards Colbun petition of suspending the studies of H.A. impact, are not only shameful but also transforms the negotiation process of citizen consultation into a fake.

This argument displays the resource of polarization through the use of keywords such as 'counterpart', 'shameful' and 'fake'. There is a perceived negative harmful counterpart that is indifferent to the needs of the locals (citizens consultation and participation) whose decision (of suspending the studies of H.A. impact) is seen as a political fake, generating a deep distrust scenario on the part of 'Patagonia without Dams'.

The above perceptions are reaffirmed by 'Aysenines against H.A.' who declare at a local digital daily:

(...)today the powerful ones [...], in detriment of the citizens, have ignored a whole region and its citizens who have witnessed on their own nose how they were being cheated and overpassed.

It is interesting how the perception of being cheated by HydroAysen enterprises is displayed by the Chilean metaphor 'on their own nose' which connotes a disrespectful and brazen action that is done directly to somebody. Aysenines perceive HydroAysen to be a tricky opponent that takes advantage of locals' disadvantaged position in decision making.

\section{Discussion}

The aim of this study was to reveal the discourse coalitions arising during the controversy around the proposed construction of the HydroAysen megaproject in the Patagonia region of Chile. Our analyses of public allocutions from various media identified two groups of actors. One group comprises the government, represented by the President of the Republic and the Ministry of Energy, and HidroAysen enterprise executives, and the other, citizens associations 'Patagonia without Dams' and 'Aysenines against HidroAysen'. These actors build their narratives around three nodal concepts and each displays affinities with their respective story lines.

The first nodal concept relates to the actors' representations of the energy situation of the country. In this node HidroAysen and the government argue that there is an existing energy crisis in the country that can only be solved by the completion of the HidroAysen project. On the other hand, 'Patagonia without Dams' and 'Aysenines against HidroAysen' share the argument that the HidroAysen project is a measure to enrich entrepreneurs in the national capital, Santiago, to the detriment of the small and distant regions in the south of Chile. The lack of an adequate national energy policy creates an urgency that fosters the perception that the project is needed, and thereby fosters this perceived favoritism.

With regard to the views about the economic and environmental development of the Aysen region, HidroAysen executives and the government claim that the hydroelectric project will enable Aysen regional development and its connectivity to the country. This group narrative is based on an anthropocentric ideology in which nature is subjected to man's economic activity, and therefore becomes a replaceable capital or, as Tietenberg (2001) calls, a commodity or service. This ideology is reflected in the act of offering the locals mitigation measures such as more work opportunities and control of predator fish species to allow stocks of threatened native fish to replenish, but do not protect the integrity of Patagonic natural and cultural heritage. On the other hand, the discourse coalition of 'Patagonia without Dams' and 'Aysenines against HidroAysen' advocates an economic development based on the conservation of Patagonic nature and culture which is perceived to be interdependent from human intervention. This ideology states that nature and the human being sustain a horizontal relationship of reciprocal respect and care. For 'Patagonia Without Dams' tourism represents an essential pillar for Aysenine development. Notwithstanding this activity may cause some harm to the natural environment, particularly the building of touristic infrastructure, for this group it is an industry directly dependent on the local resources, positioning natural environment above human economic activity.

The third nodal concept concerns the role of citizens in society's decision making. Both the government and HidroAysen assign the public a passive role, as mere recipients of information. This role is of unidirectional character, there is information passed on from the government and HydroAysen executives to the citizen without the opportunity for an active participation in decision making. This asymmetric relational pattern is to the detriment of citizens. On the other hand, the 'Patagonia without Dams' and 'Aysenines against HydroAysen' discourse coalition demand an active role for citizens in policy and decision making, at both regional and national levels.

The situation described above makes it hard for actors of two antagonistic coalitions to agree and reach consensus due to the absence of mutual trust. Moreover, 'Patagonia without Dams' and 'Aysenines against HidroAysen' coalition lacks concrete and effective channels for participation in decision making, and this keystone of democracy is 
overlooked and obstructed by the government and HidroAysen. The overriding of citizen rights is a repetitive pattern in Latin America (Khagram, 2004; Castro, 2008; Ascelrad, 2010; Landa, 2012), where the pattern underlying the HidroAysen conflict can be observed in various countries in which local communities collide with big enterprises (Folchi, 2001; Khagram, 2004; Toledo et al, 2009; Perez, 2009; Bingham, 2010; Landa, 2012; Abbink, 2012; OLCA, 2013).

The above asymmetry results in the discursive institutionalization of the government and HidroAysen coalition which was operationalized by the establishment of hydroelectricity as one of the pillars of the Chilean energy matrix in the 'National Energy Strategy Plan 2012-2030' in 2012. This coalition is able to reach institutionalization because the government holds the political and administrative tools for power imposition, making its institutionalized discourse credible and necessary (Hajer, 1995). The dominated coalition is then left with little active participation and argumentative resources to incorporate their alternative proposal, which centers on non conventional renewable energy, into the 'National Plan for Energy Development'. However this proposal has gained ample public support. Similar discursive institutionalizations are reported in the cases of the Sardar Sarovar dam in India (Mehta, 2001), the Gabe dam in Ethiopia (Abbink, 2012), and the Danube Circle in Hungary (Williams, 1994).

Our study shows that from a sociopolitical perspective no consensus between groups has been reached and citizens' voices in this important issue, particularly Aysenines, are marginalized. Moreover, Chilean institutional channels for citizens' rights in decision making are weak and many times obstructed. As a result, social actors are currently organized and have generated their own mechanisms to exert their rights (Shiva et al, 1991; McCully, 2001; Khagram, 2004). Street demonstrations have become their method of having their voices heard in the hope that they can eventually become institutionalized. These activities draw together a diverse group of interested actors such as indigenous communities, academics and local community members, thereby generating an alternative political force. This 'bottom-up' sociopolitical phenomenon seems to be a social action that may persist through various generations until a real and substantive democracy is installed in Chile.

From the discourse analysis perspective our analysis demonstrates how metaphors are used as a rhetoric tool in the construction of persuasive arguments to dramatize and produce more vivid, exemplifying and convincing effects on the public. Furthermore the HydroAysen case contributes to our knowledge by highlighting and explaining the role discourse coalitions may play in contributing to the failure of Chilean democracy to build social consensus on contentious issues.

\section{References}

Abbink. J (2012). Dam controversies: contested governance and developmental discourse on Ethiopian Oms River Dam. Social Anthropology/Anthropologie Sociale (2012) 20, 2 125-144. C 2012 European Association of Social Anthropologists. http://dx.doi.org/10.1111/j.1469-8676.2012.00196.x

AIDA. (2009). Grandes Represas en América: ¿Peor el remedio que la enfermedad? [Large dams in America: medicine worse than illness?]. ISBN 978-0-9823143-1-9. Copyright Asociación Interamericana para la Defensa Ambiental.

Ascelrad, H., Bezerra. G., Gavira, E. (2010). Inserción económica internacional y 'resolución negociada' de conflictos ambientales en Latina [international economic insertion]. EURE. 36 (107). 27-47.

Bingham, A. (2010). Discourse of Dammed. Polis. 4. 1-47.

Castilla, F., \& Leyton, M (2010). Turismo en la región de Aysén y la Patagonia chilena [Tourism in Aysen region and Chilean Patagonia]. Revista Interamericana de Ambiente y Turismo. 6 (2). RIAT Revista Interamericana de Ambiente y Turismo. 6 (2). 92-97.

Castro, J. (2008). Water struggles, Citizenship and Governance in Latin America Development, 51, (72-76) r 2008 Society for International Development 1011-6370/08. www.sidint.org/development.

Diario La Nación. (Miércoles 30 de Mayo, 2012). Colbún paraliza su proyecto de transmisión para HidroAysén.[Colbun stops its transmission project to Hydroaysen]. Retrieved from http://www.lanacion.cl/colbun-paraliza-su-proyecto-de-transmision-para-hidroaysen/noticias/2012-05-30/185752.h tml

De la Maza. G. (2012). Responsabilidad social empresarial, politica e internacionalización. El caso del 'conflicto de los cisnes' en Valdivia, Chile. [Sociopolitical and entrepreneurship responsibility and internationalization. The case of the 'Swans conflict']. 12 (70) 167-201.

Edmonds, R. (1992). The Sanxia (Three Gorges) Project: The Environmental Argument Surrounding China's Super Dam. Global Ecology and Biogeography Letters, 2(4).105-125.

Edwards, D. (1997). Discourse and Cognition. London: Sage. 
Folchi. M. (2001). Conflictos de contenido ambiental y ecologismo de los pobres: no siempre pobres, ni siempre ecologistas. Ecología Política, 22. 79-100.

Fuenzalida. M., \& Quiroz. R. (2012). La dimensión espacial de los conflictos ambientales en Chile [Spatial dimensión in environmental conflicts in Chile]. Polis. 31.

Foucault, M. (1984). The archaeology of Knowledge. London: Tavistock Publications.

Hvistendahl, M. (2008). China's Three Gorges Dam: An Environmental Catastrophe? Scientific American, March 25.

Hajek, E., \& Camus, P. (1990). Historia Ambiental de Chile. [Environmental History of Chile], Editorial Pontificia Universidad Católica de Chile.

Hajer, M. (1995). The Politics of Environmental Discourse: Ecological Modernization and the Policy Process. Oxford: Oxford University Press.

Hajer, M. (2005). Coalitions, practice and meaning in environmental politics: from acid rain to BSE. In Howarth \&Torfing Discourse Theory in European politics, identity, Policy and Governance. Editorial Matter and Selection, 297-315.

Hajer, M., \& Versteeg, W. (2005). A decade of Discourse Analysis of environmental politics: Achievements, challenges, perspectives. Journal of Environmental Policy Planning, 7(3) 175-184.

Hirsh, C., \& Utreras, M. (2010). Hidroeléctricas, los derechos de los pueblos indígenas y resistencia popular en Guatemala. [Hydroelectic, indigenous peolples' rights and citizens' opposition in Guayemala] La Asociación de Estudios Internacionales de Agua (FIVAS). Osterhausgate 27, N-0183 Oslo, Noruega. Tel: +47 22989325 correo: fivas@fivas.org.

Howarth, D., Norval, A., \& Stavrakakis, Y. (2000). Discourse Theory and Political Analysis. Identities, Hegemonies and Social Change. Manchester \& New York: Manchester University Press.

Jefferson, G. (2004). Glossary of transcript symbols with an introduction. In G. Lerner (Ed.), Conversation Analysis: Studies from the First Generation. Amsterdam: John Benjamins.

Jongerden, J. (2010). Dams and Politics in Turkey: Utilizing Water, Developing conflict. Journal Compilation 2010, Middle East Policy Council. Article first published online: 15 MAR 2010. http://dx.doi.org/10.1111/j.1475-4967.2010.00432.

Khagram, S. (2004). Dams and development transitional struggles for water and power. Cornell University Press.

Laclau, E., \& Mouffe, C. (1985). Hegemony and Socialist Strategy: Towards Radical Democratic Politics. London.

Landa. O. (2012). La lucha legal por la justicia hídrica: México en el Tribunal Latinoamericano del Agua. [Legal struggle for hydric justice: Mexico in Latinamerican Court for Water]. El Cotidiano 173.

Latta, A. (2010). Generating consent mega-hidro and the post neoliberal corporations. The case of Hydroaysen. Presented at the WATERLAT International Conference. São Paulo, Brazil, October 2010. Retrieved from http://my-test-wiki-2010.wikispaces.com/file/view/GENERATING+CONSENT--Latta.pdf

Diario La Tercera. (2011). 74\% rechaza HidroAysén. Retrieved from http://diario.latercera.com/2011/05/15/01/contenido/reportajes/25-69083-9-74-rechaza-hidroaysen.shtml

McCully, P. (2001). Silenced Rivers: The Ecology and Politics of Large Dams. Zed Books, Dec 7, 2001 -Business \& Economics.

Ministerio de Energía de Chile. (2012). Estrategia Nacional de Energía 2012-2030 [National Energy Strategy 2013-2030]. Retrieved from http://www.minenergia.cl/estrategia-nacional-de-energia-2012.html

Montoya-Aguilar, C. (2009). Salud, cambio climático y contaminación. Actualización acerca de las fuentes alternativas de energía en Chile. [Health, climate change and contamination. Updating alternative sources of energy in Chile]. Cuadernos Medico Sociales, 49(4). 235-237.

Montreal, P., Diaz, O., Córdova, H., Gerber, E., Gonzalez, L., Liberona, F., Namuncura, D., Urrutia, E., Rodriguez, A., Rodriguez, P., Scantlebury, M., Silva, P., \& Varas, A. (2012). A mitad de camino. Punto de no retorno [In midway. No return point] Fundación Equitas y Fundación Friedrich Ebert.

OLCA. (2013). (12 de Diciembre de 2013) Los mundurukú se levantan contra megaproyecto hidroeléctrico. [Munduruku raise against hydroelectric megaproject] Retrieved from http://olca.cl/articulo/nota.php?id=103885

Rigg, J. (1991). Nam Choan Dam Project, Thailand. Global Ecology and Biogeography Letters, 1(2). 42-54. 
Routledge, P. (2003) Voices of the dammed: discursive resistance. Political Geography 22 (2003) 243-270. @ 2003 Elsevier Science Ltd. All rights reserved. http://dx.doi.org/10.1016/S0962-6298(02)00095-1.

Salinas. R., \& Carmona. A. (2009). Conflictos por el agua en Chile: el gran capital contra las comunidades locales. Análisis comparativo de las cuencas de los ríos Huasco (desierto de Atacama) y Baker (patagonia austral). Espacio Abierto: Cuaderno Venezolano de Sociología, 18(4), 695-708.

Shiva, V. (1991). Ecology and politics of survival: conflict over natural resources in India. Research Foundation for Science, Technology and Ecology, New Delhi.

Svampa, M. (2012). Consenso de los Commodities, Giro Ecoterritorial y Pensamiento crítico en América Latina.[Commodities consensus, ecoterritorial and critical thought in Latin America]. OSAL. 13 (32).

Tietenberg, T. (2001). Emissions trading programs. Published by Ashgate Publishing Limited Gower House Croft Road Aldershot Hants GU11 3HR England, Ashgate.

Toledo, H., Aravena, H., \& Olivares, X. (2009). Agua, poder y discursos: Conflictos socio territoriales por la construcción de centrales Hidroeléctricas en la Patagonia chilena. [Water, power and discourses: Socioterritorial conflicts around the building of Hydroelectrics in Chilean Patagonia]. Anuario de Estudios Americanos. 66 (2). $81-103$

Plan Nacional de Desarrollo $\quad$ Energético. Retrieved from http://www.patagoniasinrepresas.cl/final/contenido.php?seccion=nuestrapropuesta

Potter, J. (2005). Making Psycology Relevant. Discourse \& Society, 16(5), 739-747.

Radio Biobio. (Enero 28, 2014) Endesa deja de mostrar HidroAysén como su proyecto estrella a inversionistas.[National Enterprise of energy development. Retrieved from http://www.biobiochile.cl/2014/01/07/endesa-deja-de-mostrar-hidroaysen-como-su-proyecto-estrella-a-inversionist as.shtml

Williams, P. (1994). Environmental Dispute Resolution: The dispute between Slovakia and Hungary concerning construction of the Gabcikovo and Nagymaros Dams. Columbia Journal of Environmental Law, 19(1), 1-57.

\section{(cc) BY}

This work is licensed under a Creative Commons Attribution 3.0 License. 